\title{
Human Rights and Declining Sex-Ratio
}

\author{
Ms. Asha Rani \\ Ms. Asha Rani, M.phil Scholar Department of Sociology University of Jammu
}

\begin{abstract}
In India, right from her birth, a girl child is treated by the society, including her parents as a burden because of various traditional beliefs and misconceptions of the society. The reaction of the family members is different towards the girl's rights right from the birth. Often, the girl is born and brought up in an atmosphere where the family would have rather preferred a boy in her place. This attitude of acceptance to large extent affects her existence. Those who survive are also discriminated against and neglected in numerous ways. Son preference has been one of the most evident manifestations of patriarchal society. In the paper both primary and secondary data were used. The present paper is an attempt to understand the socio-cultural factors that have traditionally undervalued daughters compared to sons and how all these practices violates many rights of these innocent girls and foetuses in Kathua district of Jатти (Jатmu and Kashmir).
\end{abstract}

Keywords: Traditional Beliefs, Discrimination, Neglected, Patriarchy, Socio-cultural, Foetus, Girl's Rights

\section{Introduction}

Son preference has been one of the most evident manifestations of patriarchal society. It has worked against the female sex particularly in their infancy and early childhood. A girl child is discriminated against in many ways - ranging from abandonment of girl children fewer months of breast feeding, less of nurturing and play, lesser medical treatment if falls ill etc, all working against the very existence of girl child. Today with the technological advancement in medical diagnosis, this discrimination begins even before her birth ${ }^{1}$.

The discrimination is rooted in a complex set of religious, economical, social and cultural factors. The degree of discrimination may vary but it definitely exists at various levels at different stages in a girl's life, affecting the fundamental rights of the girl child for her overall development. The mortality rate of young girls of different age groups is much higher than young boys because of the preference for male children, resulting in the neglect of girl children. The hatred towards a girl child has grown up so much and brought into the system of eliminating the girl child - the vulnerable and unwanted gender, in the womb, before she sees the world. The sex ratio is already precarious owing to the discrimination against daughters. Abortion of unborn daughters is bound to accelerate the downward slide of female along the demographic ladder. ${ }^{2}$ Thus this paper on 'Declining Sex-ratio in Kathua district (Jammu, J\&K)' appears to be a voice for the rights of many unborn and unfortunately-born girls of Kathua district which sees a very low sex-ratio of 877 as per 2011 Census.

All over the world, the ratio of female-male population is favorable for women except in developing countries like India, where males outnumber females. Its declining sex ratio is an issue of grave concern. The sex ratio in India has declined drastically since 1961 from 976 to 927 in 2001. The provisional data released by the census office 2011 shows that the sex ratio has further declined to 914 girls for every 1000 males as compared to 927 in 2001. Jammu \& Kashmir has shown a fall of 9 points in 2011 as compared to 2001 census with its child sex ratio falling to 883 as compared to 892 respectively in 2001 making it the third worst state after Haryana and Punjab. Some districts have shown improvement while the others have shown decline. Kathua has shown a decline from 898 in 2001 to 877 in 2011. Kathua ranked at $12^{\text {th }}$ position in 2001 while it has now dipped to $14^{\text {th }}$ position as far as the district wise sex ratio in the state of $\mathrm{J} \& \mathrm{~K}$ is concerned. ${ }^{3}$

The persistence of social attitude and prejudices against girls continues to raise considerable concern for human rights defenders of Girl Children. Girls are often neglected in their access to nutrition, health care and education. They are deprived of their childhood by being domestic workers or farm workers or child labourers in different work places. They are often the target and victims of gender discrimination, violence, sexual exploitation and abuse. Amongst all her very right to be born and right to life is taken away by practices of sex selective abortions and infanticide, which is a human rights violation and violation against the provisions enshrined in the Indian Constitution and Child Rights Convention (1889, United Nations). The World Conference on Human Rights (1993, Vienna, Austria) affirmed that the rights of the girl child are inalienable, integral and indivisible part of human rights and the eradication of all forms of discrimination on the ground of sex is to be considered as a priority objective of the international community. The final document on the International Conference on Population and Development held at Cairo (1994) has encouraged the government to rise the minimum age of marriage and recognised that the age of marriage was a factor contributing to the violations of human rights. ${ }^{4}$ 
The Beijing Platform for Action, adopted at the Fourth World Conference (1995) on Women, included "the Girl Child" in its 12 critical areas of concern. It recognizes that in many countries, the girl child faces discrimination in all stages of life from birth through childhood and into adulthood. Some of the strategic objectives formulated under "the Girl Child" are as follows:

1. Eliminate all forms of discrimination against the girl child,

2. Eliminate negative cultural attitudes and practices against girls,

3. Promote and protect the rights of the girl child and increase awareness of her needs and potential,

4. Eliminate discrimination against girls in education, skills and development and training,

5. Eliminate discrimination against girls in health and nutrition,

6. Eradicate violence against the girl child,

7. Promote the girl child's awareness and participation in social, economic and political life.

But all this can be done only when the girl child is born. It has been found that there is the urgent need of addressing the issue of the violation of the very basic right of a girl to take birth. The figures given above are manifest enough to prove that many a girls are not even let to see this world just because they are girls. And for the same reason they are deprived of their very basic and fundamental right to take birth or the right to life.

\section{Right to Life}

The right to life is a phrase that describes the belief that a human being has an essential right to live, particularly that a human being has the right not to be killed or deprived of their life by another human being or the state. Article 3 of the Universal Declaration of Human Rights (UDHR) stipulates: "Everyone has the right to life, liberty and the security of person". Article 6 (1) of International Covenant on Civil and Political Rights (ICCPR) also stipulates: "Every human being has the inherent right to life. This right shall be protected by law. No one shall be arbitrarily deprived of his life". The right to life is enshrined in UDHR and in ICCPR, making it a legally enforceable and non-derogable right in every United Nations member state. ${ }^{5}$

In the study majority of the respondents accepted that there is nothing wrong in having sex-selective abortions. $66.67 \%$ of the female responded that they had aborted a girl child. There were some who had gone for repeated abortions. In a particular case a woman had five abortions to eliminate girl child. From the above data it clearly shows that many girls' right to life has been violated. In sex-selective abortion cases, a female fetus' right to life is violated.

\section{Girl's right to freedom from neglect}

The right to health is closely related to other Articles in the Convention on the Rights of the Child (CRC), freedom from discrimination (Article 2), the right to survival and development (Article 6) and protection from abuse and neglect (Article 19). Children who suffer discrimination, violence, neglect, abuse, or other violations of their rights under the Convention on the Rights of the Child (CRC) are also particularly vulnerable to violations of their right to health. ${ }^{6}$

As observed during the fieldwork some of the girls were not healthy. They were discriminated in nutrition and looked weaker in comparison to their male siblings. Their parents also admitted that they did not find it important to feed their daughters at par with their sons because they did not have to work as hard as the boys and it was also useless to water your neighbour's plants. They were regarded as 'paraya dhan' and needed not to be fed at par with their own wealth, their sons.

Girls were also discriminated in education. They were sent to the nearby government schools and boys were sent to private schools. Girl children were not allowed for higher education, they were at the home for doing household chores as it was more important for a girl to learn the ABC of cooking and other household work than the $\mathrm{ABC}$ of academics. They were neglected by their family members in almost all the aspects including their love and blessings that were all reserved for the sons.

As often said that it is mainly a woman who discriminates between a boy and a girl but let me quote a surprising fact here that 80 percent men as against 33.34 percent women and 46.67 percent mothers-in-law do discriminate between a boy and a girl. The reasons put forward by men for such discrimination were- it is a burden to have a daughter as they have to bear the expenses of their marriage which includes a huge stock of dowry as a mark of status and honour for the girl. Moreover there is always a threat of a girl bringing bad name to the family by having love affairs with boys and also if she has been sexually exploited by someone. So there is always a sort of nervousness in the family to keep the girl protected from all sorts of dangers. Another interesting fact that should be relevant to be mentioned here is that though all the people were suffering because of this practice of dowry yet all of them, 100 percent, wanted to have dowry at the time of their son's marriage. The women though had the same reasons too behind not preferring to having a daughter; they had another important reason as to who will carry their name forward if they did not have a son. A son was seen as the 'kuldeepak'. 


\section{Right to equal opportunity}

With all these substantive observations, we can clearly see that the girls are first not let to take birth and those who are given their right to see this world are further given another kind of death everyday by discriminating them in all walks of life and comparing them with boys' who are considered superior to girls and thus 'achhi cheez' (blessing). It can often be heard by the elderly people blessing the expecting mothers to have an 'achhi cheez' (son) or cursing someone to have a daughter. In such a situation where a girl is given birth, she is deprived of many opportunities.

Apart from the opportunities like access to education, nutrition etc. there were many other occasions when they were discriminated against right from the birth. In many cases, it was noted that the mother did not even like to breast-feed the new born just because she was a girl. There were no celebrations at the time of the girl's birth. 60 percent families performed lavish ceremonies at the time of a son's birth while only 20 percent performed it at a girl's birth but the celebrations were not that lavish. It was just a part of their ritual which they have to perform in any case.

Even the hospital staff does not demand 'badhai' at the birth of a girl child who would otherwise ask for thousands of rupees. They never dare to congratulate the parents at a girl's birth. A local 'dai' who used to go for deliveries reported that people shower money and even gold jewellery at her when she informs the family about the birth of a son. Even the "khusras" do not come to ask for their share if they know the new born is a girl.

So the rights to equal opportunity, the right to live in an abuse and neglect free atmosphere, the right to health and the most importantly the right to life have been openly violated in these and many other families and it has become a part of their sub-culture without giving any second thought to it. The persistent tradition, prejudices and traditional role distributed within the family are the key factors affecting the enjoyment of girls' fundamental rights. It has even resulted in the elimination of girl children in the form of foeticide and infanticide.

Many women become instrumental in committing such heinous crimes like aborting the girl child before they are born. In many cases, a woman aborts her female foetus in response to societal pressure but there are also instances when the woman herself makes the decision. Social practices like lavish marriages of daughters, dowry, providing safety to girls from sexual harassment even inside the home continue to rule the roost. $^{7}$

Thus the various reasons for son preference like performing the last rites of parents, reluctance towards having daughters and other socio-cultural factors that discourage women to give birth to daughters are a big reason for the declining sex- ratio and violation of rights of girl children in the Kathua district.

\section{Methodology}

For the collection of the data, both primary and secondary sources including the various quantitative and qualitative techniques have been used during the study. The structural approach has been used keeping in view the patriarchal social structure of the research area that has led to the decline in sex ratio.

\section{Objectives of the Study}

- To examine the present trends in sex-ratio and assess the interplay between the various socio-cultural factors and the declining sex ratio in district Kathua which violates the human rights of the most vulnerable section of the society.

- To understand the nature of prejudice and discrimination against the girl child this is again a violation of their rights.

\section{Findings And Conclusion}

Many women become instrumental in committing such heinous crimes like aborting the girl child before they are born. In many cases, a woman aborts her female foetus in response to societal pressure but there are also instances when the woman herself makes the decision.

Son preference is thus deeply embedded in our socio-cultural practices that find relevance in our religious literature. Even after attaining a better literacy level, improved health standards, we have not been able to get rid of our old practices.

Social practices like lavish marriages of daughters, dowry, providing safety to girls from sexual harassment even inside the home continue to rule the roost. Thus the various factors such as son preference, reluctance towards having daughters and other socio-cultural factors that discourage women to give birth to daughters are the main reasons for the declining sex- ratio and the violation of rights of girl children in the Kathua district. 


\section{References:}

[1] Daily Excelsior (8.4.2011).

[2] www.aidwaonline.org/category/reports-struggle/aidwa against declining sex ratio. (28.6.2012).

[3] The Times of India, New Delhi. (8.4.2011).

[4] Liu Liantri "The Comparison between UDHR and Chinese Constitution, CCP" Zhejiang Provisional Committee Party School Journal Vol. 5. 1999.

[5] Op.cit. Ref. 2

[6] Op.cit. Ref. 4

[7] Patel, Tulsi "Sex-Selective Abortion in India" Sage Publication, New Delhi, 2007. 